\title{
AKTIVITAS SIDEROFOR BACILLUS SUBTILIS SEBAGAI PEMACU PERTUMBUHAN DAN PENGENDALI PATOGEN TANAMAN TERUNG
}

\author{
Nur Prihatiningsih'1, Heru Adi Djatmiko ${ }^{1}$ \& Puji Lestari² \\ ${ }^{1}$ Jurusan Agroteknologi, Fakultas Pertanian, Universitas Jenderal Soedirman \\ ${ }^{2}$ Jurusan Kimia, Fakultas Matematika dan Ilmu Pengetahuan Alam, Universitas Jenderal Soedirman \\ J1. dr. Suparno Purwokerto 53123 \\ E-mail: prihatiningsihnur@gmail.com
}

\begin{abstract}
Siderophore activity of Bacillus subtilis as plant growth promoters and biological control agent of eggplants pathogens. The aims of this research were to identify the siderophores of B. subtilis, to assess its activities as plant growth promoters and biological control agent of eggplants pathogens. Five isolates of B. subtilis i.e.B46, B209, B211, B298 and B 315 grown on SD-CASA medium. The isolate which showed the best siderophores production was then further studied on its ability as a growth promoter on eggplants in two soil types with different Fe content. The inhibitory test was conducted against two kinds of pathogens, namely Colletotrichum sp. and Ralstonia solanacearum. The greenhouse experiment was arranged using a factorial completely randomized block design. The first factor was the B. subtilis (B. subtilis B298 and without B. subtilis B298), second factor was the type of soil (Ultisol and Andisol). The variables measured were Fe uptake by plants, plant growth parameters on eggplant i.e. height, leaf number, root length, root volume, weight of fresh and dried shoot as well as fresh and dry root, percentage of inhibition to fungal and bacterial eggplant pathogens. The results showed that the five isolates of $B$. subtilis were able to produce siderophores as catecholate and hydroxamate types. The best siderophore production was showed by B. subtilis B298. The ability of B. subtilis B298 in accelerating the growth of plants was indicated by the increased of uptake Fe, plant height, leaf number, root volume, weight of dried plants by $45.62 \%$, $25.48 \%, 19.45 \%, 41.10 \%$ and $34.89 \%$ respectively. The inhibition to the fungal and bacterial eggplant pathogens best shown by the isolates of $B$. subtilis B298 with $55.4 \%$ and $22 \mathrm{~mm}$ respectively.
\end{abstract}

Key words: Bacillus subtilis, siderophore, cathecolate, hydroxamate, growth of eggplants, inhibition to pathogens

\section{ABSTRAK}

Aktivitas siderofor Bacillus subtilis sebagai pemacu pertumbuhan dan pengendali patogen tanaman terung. Penelitian ini bertujuan untuk mengidentifikasi siderofor dari B. subtilis, menilai aktivitasnya sebagai pemacu pertumbuhan, dan pengendali patogen tanaman terung. Lima isolat B. subtilis yaitu B46, B209, B211, B298 dan B 315 ditumbuhkan pada medium SD-CASA. Isolat yang dapat memproduksi siderofor terbaik ini selanjutnya diuji kemampuannya sebagai pemacu pertumbuhan tanaman terung pada dua jenis tanah dengan kandungan Fe berbeda. Uji penghambatan dilakukan terhadap dua macam patogen, yaitu Colletotrichum sp. dan Ralstonia solanacearum. Percobaan di rumah kaca dirancang menggunakan Rancangan Acak Kelompok Faktorial dengan 2 faktor. Faktor pertama adalah B. subtilis (dengan B. subtilis B298 dan tanpa B. subtilis B298), faktor ke dua adalah jenis tanah (Ultisol dan Andisol). Variabel yang diamati antara lain serapan Fe oleh tanaman dan parameter pertumbuhan tanaman terung meliputi tinggi tanaman, jumlah daun, panjang akar, volume akar, bobot segar dan kering tanaman serta bobot segar dan kering akar, persentase penghambatan terhadap jamur dan bakteri patogen. Hasil penelitian menunjukkan bahwa kelima isolat $B$. subtilis mampu menghasilkan siderofor tipe catecholat dan hydroxamat dan produksi siderofor terbaik ditunjukkan oleh B. subtilis B298. Kemampuan B. subtilis B298 dalam memacu pertumbuhan tanaman ditunjukkan dengan adanya peningkatan serapan $\mathrm{Fe}$, tinggi tanaman, jumlah daun, volume akar, bobot kering tanaman secara berturut-turut sebesar 45,62\%, 25,48\%, 19,45\%, 41,10\% dan 34,89\%. Penghambatan terhadap jamur dan bakteri patogen yang terbaik ditunjukkan oleh isolat B. subtilis B298 yaitu 55,4\% dan $22 \mathrm{~mm}$.

Kata kunci: Bacillus subtilis, siderofor, cathecolat, hydroxamat, pertumbuhan tanaman terung, penghambatan patogen 


\section{PENDAHULUAN}

Bakteri antagonis merupakan bakteri yang mempunyai sifat mampu mengendalikan patogen dan meningkatkan pertumbuhan tanaman yang juga disebut sebagai PGPR (plant growth promoting rhizobacteria). Bakteri antagonis umumnya hidup mengkolonisasi akar dan bersifat menguntungkan, karena mampu meningkatkan pertumbuhan tanaman dan menginduksi ketahanan sistemik (Choudhary \& Johri, 2009). Selain mengkolonisasi akar, bakteri antagonis juga berada pada permukaan akar (rizoplan) atau di dalam jaringan radikular (Kloepper et al., 1989; Dawwam et al., 2013). Salah satu bakteri yang secara luas telah dilaporkan sebagai antagonis adalah Bacillus subtilis. Bakteri ini mampu berperan sebagai antagonis melalui mekanisme antibiosis dan kompestisi baik ruang maupun nutrisi (Beneduzi et al., 2012).

Prihatiningsih \& Djatmiko (2016) dan Lestari et al. (2017) melaporkan bahwa Bacillus subtilis asal rizosfer kentang isolat B315 (mampu menghasilkan enzim amilase) dan isolat B298 (menghasilkan kitinase) terbukti mampu menekan pertumbuhan jamur patogen tanaman. Pengendalian hayati menggunakan B. subtilis B315 terhadap bakteri layu pada kentang juga telah dilakukan dan menunjukkan mekanisme antibiosis (Prihatiningsih et al., 2015). Morikawa (2006) menyebutkan bahwa $B$. subtilis mampu menghasilkan enzim amilase, protease, pullunase, chitinase, xylanase dan lipase yang merupakan metabolit sekunder untuk mengendalikan patogen dan memacu pertumbuhan tanaman.

Selain berperan sebagai PGPR, bakteri antagonis juga dapat berperan sebagai biofertilizer dan bioenhancer bagi tanaman. Bakteri antagonis sebagai biofertilizer karena bakteri tersebut mampu memperbaiki pertumbuhan akar dan nutrisi (Egamberdiyeva \& Hoflich, 2004). Peranan bakteri antagonis sebagai PGPR dapat dilihat dari kemampuannya untuk menghasilkan siderofor, IAA, sebagai pelarut fosfat, dan pemfikasasi nitrogen. Siderofor adalah senyawa berbobot molekul rendah yang mampu mengkhelat besi $\left(\mathrm{Fe}^{3+}\right)$, dan responsif untuk pelarutan serta pengangkutan elemen ini ke dalam sel bakteri (Sharma \& Johri, 2003). Pada kondisi keterbatasan besi, mikroorganisme penghasil siderofor dapat mengikat dan mengangkut kompleks siderofor-besi dengan mengekspresikan protein spesifik (Nudel et al., 2001). Kelompok bakteri yang mampu menghasilkan siderofor menguntungkan untuk tanaman karena dapat menekan patogen. Besi merupakan elemen vital dalam aktivasi enzim yang mendukung ketahanan tanaman terhadap patogen. Hingga saat ini terdapat dua tipe siderofor yaitu catecholat dan hydroxamat (Neilands \& Nakamura, 1991).

Dalam penelitian ini peranan siderofor yang dihasilkan oleh bakteri antagonis sebagai faktor pemacu pertumbuhan tanaman diuji pada 2 jenis tanah (Ultisol dan Andisol) dengan kandungan besi yang berbeda. Tanah Ultisol dikenal juga dengan tanah podsolik merah kuning merupakan tanah marginal dengan warna oranyemerah, bersifat asam, dengan kandungan fosfor tinggi. Warna merah pada tanah ini karena kandungan $\mathrm{Al}, \mathrm{Fe}$ dan Mn yang tinggi. Tanah Andisol merupakan bentukan dari abu vulkanik, berwarna hitam kelabu sampai cokelat dan merupakan tanah yang produktif untuk tanaman hortikultura.

Tujuan penelitian ini adalah untuk mengetahui produksi siderofor sebagai senyawa yang dihasilkan oleh lima isolat B. subtilis asal rizosfer kentang dan mengevaluasi aktivitasnya sebagai pemacu pertumbuhan serta mengendalikan jamur dan bakteri patogen tanaman terung.

\section{METODE PENELITIAN}

Tempat dan Waktu Penelitian. Penelitian dilaksanakan di Laboratorium Perlindungan Tanaman dan Rumah Kaca Fakultas Pertanian UNSOED dimulai Agustus 2015 sampai Maret 2016.

Perbanyakan Isolat B. subtilis. Lima isolat $B$. subtilis yang digunakan berasal dari rizosfer kentang dengan nomor isolat B46, B209, B211, B298 dan B315. Isolat ini diperbanyak pada medium Yeast Peptone Glukosa Agar (YPGA) (5 g ekstrak yeast, $10 \mathrm{~g}$ bacteriological peptone, $10 \mathrm{~g}$ glukosa, $20 \mathrm{~g}$ agar) (Lelliot \& Stead, 1987).

Deteksi Siderofor yang Dihasilkan oleh B. subtilis. Pengujian sebagai penghasil siderofor dilakukan berdasarkan metode yang dilakukan oleh Shin et al. (2001) dengan menggunakan medium simple doublelayered Chrome Azurol Sulphonate Agar (SD-CASA). Medium ini dibuat dengan cara: 60,5 mg Chrome azurol $\mathrm{S}$ (CAS) dilarutkan dalam $50 \mathrm{~mL}$ air suling dan dicampur dengan $10 \mathrm{~mL}$ larutan besi (III) $(1 \mathrm{mmol} / \mathrm{L} \mathrm{FeCl} 3.6 \mathrm{H} 2 \mathrm{O}$ $10 \mathrm{mmol} / \mathrm{L} \mathrm{HCl}$ ), sambil dishaker, larutan ini ditambah secara perlahan 72,9 mg HDTMA yang dilarutkan ke dalam $40 \mathrm{~mL}$ air. Hasil larutan yang berwarna biru gelap dilarutkan dengan $2000 \mathrm{ml}$ air, agar $2 \% \mathrm{w} / \mathrm{v}$ ditambahkan untuk pemadat, kemudian diautoklaf $121^{\circ} \mathrm{C}$ selama 15 menit. Cawan Petri berdiameter $9 \mathrm{~cm}$ disiapkan untuk plate agar (CASA) sebanyak $10 \mathrm{~mL}$ sebagai dasar plate. Setelah memadat dilapis lagi dengan medium Nutrient 
Agar (NA) sebanyak $6 \mathrm{~mL}$, dan diinkubasi semalam pada suhu $32^{\circ} \mathrm{C}$.

Untuk mengamati pengaruh $\mathrm{pH}$ terhadap pembentukan siderofor digunakan paper-disc. Paperdisc steril berdiameter $5 \mathrm{~mm}$ diletakkan pada plate agar yang telah diinkubasi 1 malam secara aseptik. Sebanyak $10 \mu \mathrm{L}$ supernatan $B$. subtilis dari sentrifugasi medium cair diteteskan pada paper-disc. Sebagai kontrol dilakukan tanpa $B$. subtilis. Pengaruh $\mathrm{pH}$ terhadap kemampuan menghasilkan siderofor dilakukan pada $\mathrm{pH}$ 5,7 , dan 9. Variabel yang diamati adalah terbentuknya zona oranye dan pink/ungu pada medium yang semula berwarna biru.

Aktivitas B. subtilis sebagai Pemacu Pertumbuhan Tanaman Terung. Pengujian aktivitas $B$. subtilis sebagai PGPR tanaman terung dilakukan di rumah kaca pada tanah Ultisol (kandungan Fe total 2391 ppm) dan Andisol (742 ppm). B. subtilis digunakan untuk perendaman benih selama 30 menit. Perlakuan berikutnya disiramkan di sekitar tanaman pada 10, 20 dan 30 hst. Penelitian disusun menggunakan Rancangan Acak Kelompok Faktorial 2 faktor dengan 6 ulangan. Faktor ke 1 adalah B. subtilis (tanpa B. subtilis B298 dan dengan B. subtilis 298). Faktor ke 2 adalah jenis tanah yaitu Ultisol dan Andisol. Variabel yang diamati meliputi serapan Fe oleh tanaman, tinggi tanaman, diameter batang, jumlah daun, panjang akar, volume akar, bobot tanaman segar dan kering, bobot akar segar dan kering. Data yang diperoleh dianalisis menggunakan sidik ragam, apabila terdapat perbedaan yang nyata dilanjutkan dengan uji Beda Nyata Terkecil (BNT) dengan tingkat kepercayaan 95\%.

\begin{abstract}
Aktivitas Penghambatan terhadap Patogen
Tanaman. Pengujian penghambatan $B$. subtilis terhadap jamur patogen dilakukan secara dual culture berdasarkan metode yang dikemukakan oleh Leelasuphakul et al. (2008) dan Muthukumar \& Venkatesh (2013), dengan menumbuhkan secara bersama berhadapan di dalam cawan Petri yang berisi medium PDA. Potongan koloni jamur patogen Colletotrichum gloeosporioides berdiameter $5 \mathrm{~mm}$ diletakkan pada medium PDA berjarak $3 \mathrm{~cm}$ dari tepi cawan Petri, kemudian digoreskan B. subtilis di sebelahnya dengan jarak $2,5-3 \mathrm{~cm}$. Pengamatan penghambatan jamur patogen menggunakan rumus Leelasuphakul et al. (2008) dan Muthukumar \& Venkatesh (2013)
\end{abstract}

$$
\mathrm{I}=\frac{\mathrm{C}-\mathrm{T}}{\mathrm{C}} \times 100 \%
$$

dengan:

$\mathrm{I}=$ persentase penghambatan

$\mathrm{C}=$ pertumbuhan jari-jari koloni yang berlawanan dengan arah bakteri antagonis

$\mathrm{T}=$ pertumbuhan jari-jari koloni yang menuju arah bakteri antagonis

Pengujian penghambatan $B$. subtilis terhadap bakteri patogen Ralstonia solanacearum dilakukan dengan metode dua lapis medium seperti dikemukakan oleh Ghosh et al.(2007) dan Prihatiningsih \& Djatmiko (2016) secara inokulasi titik, setelah 2 hari inkubasi pada tutup cawan Petri diberi chloroform $0,5 \mathrm{~mL}$ dibiarkan 2-3 jam sampai chloroform menguap. Biakan murni bakteri patogen $R$. solanacearum berumur 2 hari pada medium YPGA miring dipanen dengan $10 \mathrm{ml}$ air steril. Sebanyak 200 iL dimasukkan ke dalam 4 mL medium agar air $0,6 \%$, selanjutnya digojog dengan vorteks kemudian dituang ke dalam cawan Petri tersebut sebagai lapis ke dua. Setelah inkubasi $24-48$ jam pada suhu $28 \pm 1^{\circ} \mathrm{C}$ terbentuk zona terang yang diukur dari tepi koloni bakteri antagonis dalam satuan $\mathrm{mm}$.

\section{HASIL DAN PEMBAHASAN}

Deteksi Siderofor yang Dihasilkan oleh $B$. subtilis. Hasil penelitian menunjukkan bahwa $B$. subtilis yang diuji mampu berperan sebagai penghasil siderofor secara kualitatif. Pada isolat B. subtilis B46 terbentuk zona berwarna pink/ungu dengan ukuran zona lebih kecil dibandingkan dengan ukuran zona dari keempat isolat lainnya (Tabel 1). B. subtilis B209, B211, B298 dan B315 menghasilkan zona oranye dengan zona terkuat adalah isolat $B$. subtilis B 298 (Gambar 1). Isolat $B$. subtilis B46 menghasilkan zona pink yang menurut Perez-Miranda et al. (2007) dan Radhakrishnan et al. (2014) adalah siderofor tipe catecholat, sedangkan keempat isolat B. subtilis B209, B211, B298 dan B315 menghasilkan zona oranye adalah siderofor tipe hydroxamat. Siderofor yang dihasilkan oleh mikroorganisme umumnya adalah tipe hydroxamat, catecholat dan karboksilat (Ahmed \& Holmstrom, 2014).

Kemampuan bakteri menghasilkan siderofor merupakan komponen penting dalam PGPR, karena siderofor mampu mengikat besi $\left(\mathrm{Fe}^{3+}\right)$ menjadi ikatan siderofor-besi yang menjadi tersedia bagi tanaman. Ukuran zona bening atau zona ungu dan oranye yang dihasilkan menunjukkan kuat lemahnya $B$. subtilis dalam menghasilkan siderofor (Gambar 2). Isolat B. subtilis B298 menunjukkan zona oranye terbesar yaitu $24 \mathrm{~mm}$. Siderofor yang dihasilkan oleh mikroorganisme, 
menguntungkan tanaman karena dapat menghambat pertumbuhan patogen. Terjadinya kekurangan $\mathrm{Fe}^{3+}$ yang dibutuhkan oleh patogen karena $\mathrm{Fe}^{3+}$ sudah terikat oleh siderofor (Sharma \& Johri, 2003). Selain itu besi merupakan elemen penting dalam perkembangan penyakit, sehingga dengan terikatnya besi oleh siderofor maka patogen kurang mampu menginfeksi, sehingga menghambat perkembangan penyakit. Jenis siderofor yang dihasilkan $B$. subtilis yang terbaik adalah pada $\mathrm{pH}$ 7. Hasil penelitian Hu \& Xu (2011) mengemukakan bahwa pH 7 adalah yang terbaik untuk Bacillus strain QM3 dalam menghasilkan siderofor.

Aktivitas Siderofor B. subtilis sebagai Pemacu Pertumbuhan Tanaman Terung. Setelah aplikasi $B$. subtilis, kandungan $\mathrm{Fe}$ total pada dua jenis tanah yang

Tabel 1. Bacillus subtilis menghasilkan siderofor tipe catecholat dan hydroxamat

\begin{tabular}{cccc}
\hline Isolat B. subtilis & Penghasil siderofor & Warna zona & Jenis siderofor \\
\hline B46 & + & ungu & Catecholat \\
B209 & ++ & oranye & Hydroxamat \\
B211 & ++ & oranye & Hydroxamat \\
B298 & ++ & oranye & Hydroxamat \\
B315 & + & oranye & Hydroxamat \\
\hline
\end{tabular}

+ menghasilkan siderofor sedang, ++: menghasilkan siderofor kuat
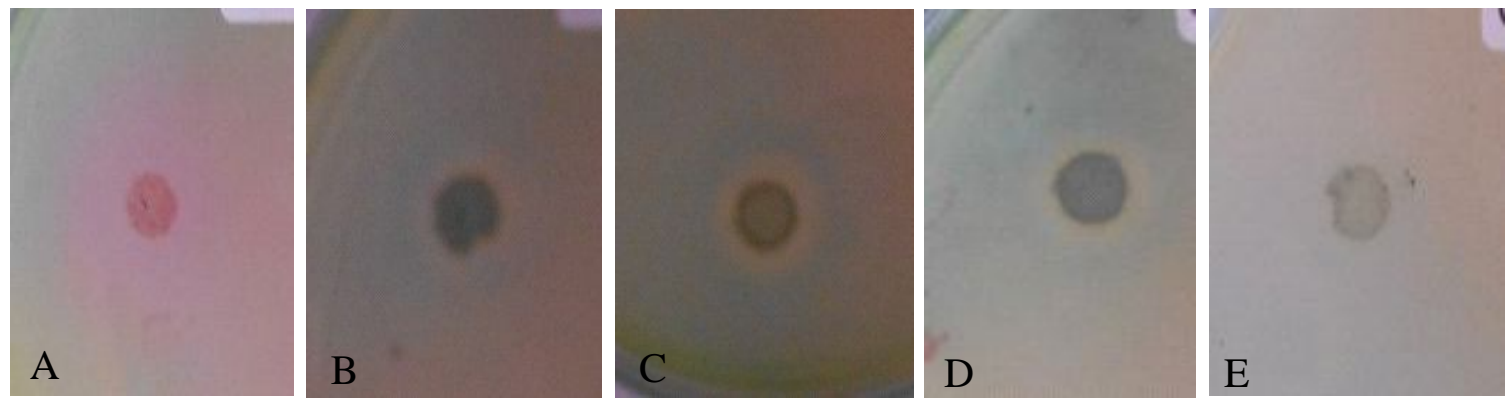

Gambar 1. Siderofor yang dihasilkan oleh lima isolat $B$. subtilis dengan zona ungu dan oranye; A. isolat $B$. subtilis B46, B. isolat B. subtilis B209, C. isolat B. subtilis B211, D. isolat B. subtilis B298, E. isolat B. subtilis $\mathrm{B} 315$.

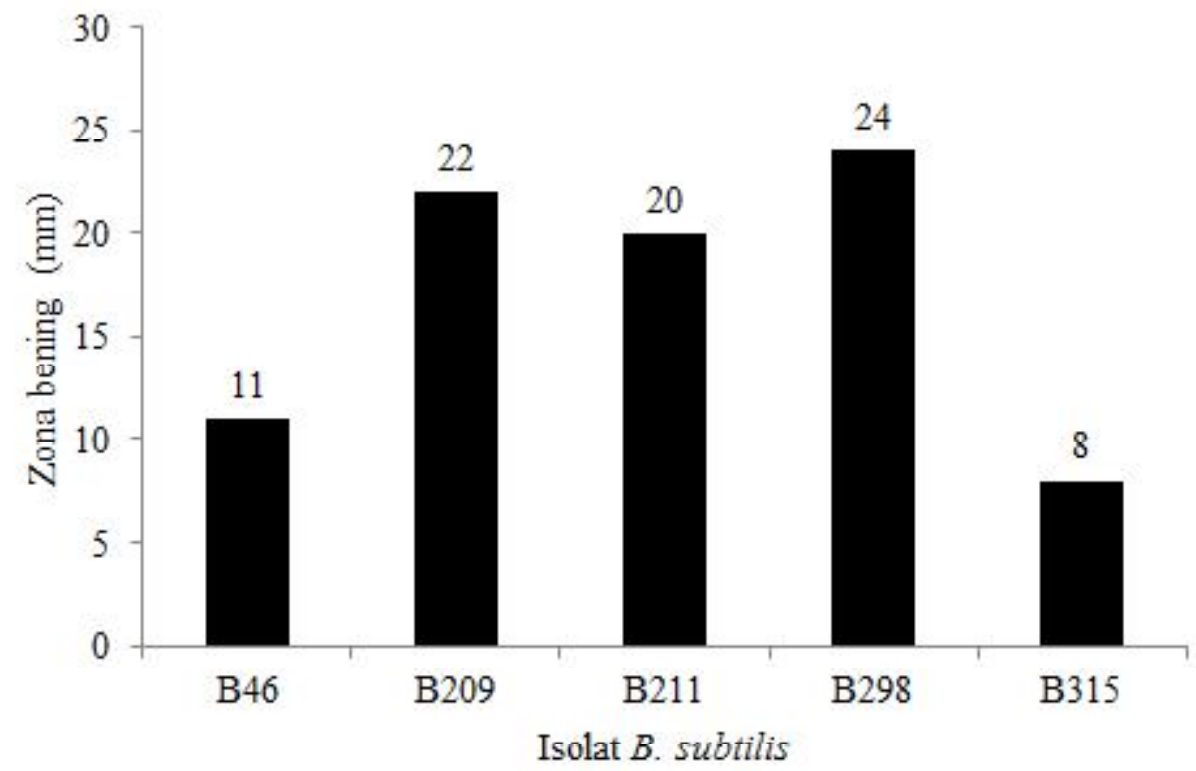

Gambar 2. Ukuran zona bening sebagai deteksi B. subtilis menghasilkan siderofor 
diuji (Ultisol dan Andisol) menunjukkan peningkatan dari 2391 ppm menjadi 2982 ppm (Ultisol) dan 742 ppm menjadi 854 ppm (Andisol). Aplikasi B. subtilis tersebut mampu meningkatkan Fe total berturut-turut sebesar $19,81 \%$ dan 13,11\%. Potensi B. subtilis B298 sebagai pemacu pertumbuhan tanaman terung didasarkan pada aktivitas siderofor yaitu serapan Fe oleh tanaman (Tabel 2). Efektivitas serapan Fe lebih tinggi pada Ultisol sebesar 45,62\% dibanding Andisol. Jenis tanah Ultisol dan Andisol memberikan pengaruh yang berbeda pada variabel serapan Fe dan luas daun. Hal ini menunjukkan bahwa Ultisol dengan kandungan Fe tinggi namun tidak tersedia bagi tanaman. Setelah aplikasi B. subtilis B298 tanaman dapat menyerap Fe lebih baik pada Ultisol sebesar 45,62\% dibanding pada Andisol. Serapan Fe oleh tanaman pada Ultisol setelah aplikasi B. subtilis meningkat sebesar 20,34\% dan Andisol 19,13\% dibanding tanpa aplikasi $B$. subtilis. Hasil ini menunjukkan bahwa $B$. subtilis menghasilkan siderofor, merubah $\mathrm{Fe}$ total menjadi Fe tersedia bagi tanaman.

Berdasarkan Tabel 2 dapat dilihat bahwa ada pengaruh interaksi antara $B$. subtilis dengan jenis tanah dilihat dari serapan Fe dan volume akar. Perlakuan tanah Ultisol dan Andisol memberikan pengaruh yang berbeda nyata pada variabel serapan Fe dan luas daun, sedangkan pada variabel lainnya tidak berpengaruh. Serapan Fe lebih tinggi peningkatannya pada Ultisol dibandingkan Andisol yaitu sebesar $20,34 \%$. Luas daun terung meningkat 18,29\% dan 12,90\% pada tanah Andisol dan Ultisol.

Perlakuan B. subtilis B298 menunjukkan pengaruh nyata pada serapan $\mathrm{Fe}$, tinggi tanaman, jumlah daun, bobot kering tanaman dan volume akar. Aplikasi B. subtilis B298 menunjukkan adanya peningkatan sebesar $19,92 \%, 25,48 \%, 19,45 \%, 41,10 \%, 34,89 \%$ secara berturut-turut pada variabel serapan $\mathrm{Fe}$, tinggi tanaman, jumlah daun, bobot kering tanaman dan volume akar. Pada tanah Ultisol terjadi peningkatan volume akar $57,70 \%$ setelah aplikasi B. subtilis B298. Hal ini menunjukkan bahwa B. subtilis B298 mampu menghasilkan senyawa yang dapat memacu pertumbuhan tanaman seperti siderofor, IAA, dan pelarut fosfat. Siderofor yang dihasilkan B. subtilis B298 membantu ketersediaan Fe bagi tanaman dan mengakibatkan pertumbuhan tanaman meningkat karena Fe dalam tanaman merupakan unsur hara esensial, berfungsi dalam fotosintesis, respirasi dan menekan serangan patogen, karena Fe juga menjadi tidak tersedia bagi patogen.

Variabel tinggi tanaman dan bobot kering tanaman terlihat meningkat disebabkan oleh tercukupinya hormon tumbuh dan senyawa yang dihasilkan oleh $B$. subtilis yaitu IAA. Medium tanam yang baik memberikan keuntungan pada tanaman untuk menyebar dan memperdalam perakaran (Compant et al., 2005). Aplikasi B. subtilis mampu meningkatkan jumlah daun sebesar $19,45 \%$ dan bobot kering tanaman sebesar $41,10 \%$, menunjukkan bahwa tanaman mampu menyerap nutrisi dengan baik. karena jumlah daun yang meningkat akan meningkatkan fotosintat, sehingga bobot kering tanaman meningkat. Siderofor hydroxamat yang terdapat di rizosfer secara efektif meningkatkan ketersediaan unsur Fe dan $\mathrm{P}$ pada tanah masam. Kemampuan pengkhelatan $\mathrm{Fe}$ tanah masam dengan kandungan $\mathrm{Fe}$ dan fosfat yang tinggi berimplikasi pada penyediaan $\mathrm{P}$ bagi tanaman sekaligus dapat meningkatkan ketahanan terhadap patogen. Bobot kering tanaman menunjukkan efektivitas penggunaan air, unsur hara dan metabolisme tanaman. Sivasakthi et al. (2014) mengatakan B. subtilis mampu meningkatkan bobot kering tanaman, yang mencerminkan banyaknya unsur hara yang terserap per satuan bobot biomassa yang dihasilkan.

B. subtilis pada Ultisol mampu meningkatkan volume akar sebesar 57,70\%. Menurut Afreen \& Chavan (2014), senyawa siderofor akan mengikat Fe kemudian mentransportkan ke dalam sel, senyawa transporter yang spesifik sebagai komponen penyusun enzim nitrogenase. Besi yang terserap digunakan untuk pertumbuhan akar sehingga mampu meningkatkan biomassa akar. Sivasakthi et al. (2014) menyatakan bahwa pemberian $B$. subtilis dalam bentuk pupuk hayati (biofertilizer) meningkatkan jumlah daun karena membantu memfiksasi nitrogen dan mengkolonisasi akar.

Penghambatan B. subtilis B298 terhadap patogen tanaman in vitro ditunjukkan dengan adanya zona terang. Fenomena ini menunjukkan mekanisme penghambatan dari B. subtilis B298 adalah antibiosis dengan metabolit sekunder yang dihasilkan seperti siderofor, enzim dan antibiotik. Tabel 3 dan Gambar 3 menunjukkan aktivitas penghambatan B. subtilis B298 terhadap jamur patogen $C$. gloeosporioides dan bakteri patogen $R$. solanacearum. Isolat B298 adalah yang terbaik, dengan aktivitas penghambatan $55,4 \%$ dan 22 mm berturut-turut terhadap $C$. gloeosporioides dan $R$. solanacearum. Hal ini menunjukkan karakter B. subtilis B298 dapat sebagai antagonis patogen tanaman. Saha et al. (2012) menyatakan bahwa $B$. subtilis strain $\mathrm{AIO} 1$ dan $\mathrm{AI} 03$ isolat terung mampu menghambat pertumbuhan $C$. gloeosporioides secara berturut-turut sebesar 74,4 dan $58,1 \%$. B. subtilis BCC 6327 yang diperoleh dari "National Center for Genetic Engineering and Biotechnology (BIOTEC) Thailand mampu menghasilkan kitinase, protease dan b-1,3-glucanase yang merupakan metabolit sekunder dan mempunyai spektrum luas sebagai aktivitas antibiotik untuk menekan pertumbuhan beberapa jamur patogen (Thakaew \& 
Tabel 2. Komponen pertumbuhan tanaman terung setelah aplikasi B. subtilis B298 pada tanah Ultisol dan Andisol

\begin{tabular}{|c|c|c|c|c|}
\hline \multirow{2}{*}{ Variabel } & \multirow{2}{*}{ Tanah } & \multicolumn{2}{|c|}{ B. subtilis } & \multirow{2}{*}{ Rerata } \\
\hline & & Tanpa B. subtilis (B0) & B. subtilis (B1) & \\
\hline \multirow{3}{*}{ Serapan Fe (ppm) } & Ultisol (T1) & 906,16 & 1137,66 & $1021,91 \mathrm{a}$ \\
\hline & Andisol (T2) & 496,91 & 614,49 & $555,70 \mathrm{~b}$ \\
\hline & Rerata & 701,535 B & 876,075 A & $(+)$ \\
\hline \multirow{3}{*}{ Tinggi tanaman $(\mathrm{cm})$} & Ultisol (T1) & 27,25 & 35,41 & $31,33 \mathrm{a}$ \\
\hline & Andisol (T2) & 24,41 & 33,91 & 29,16 a \\
\hline & Rerata & 25,83 B & 34,66 A & $(-)$ \\
\hline \multirow{3}{*}{ Diameter batang (mm) } & Ultisol (T1) & 11,53 & 12,09 & $11,81 \mathrm{a}$ \\
\hline & Andisol (T2) & 10,29 & 12,96 & $11,63 \mathrm{a}$ \\
\hline & Rerata & $10,91 \mathrm{~A}$ & $12,53 \mathrm{~A}$ & $(-)$ \\
\hline \multirow{3}{*}{ Jumlah daun (helai) } & Ultisol (T1) & 14,33 & 17,16 & $15,75 \mathrm{a}$ \\
\hline & Andisol (T2) & 15,33 & 19,66 & 17,5 a \\
\hline & Rerata & $14,83 \mathrm{~B}$ & 18,41 A & $(-)$ \\
\hline \multirow{3}{*}{ Luas daun $\left(\mathrm{cm}^{2}\right)$} & Ultisol (T1) & 192,58 & 221,10 & $206,84 \mathrm{~b}$ \\
\hline & Andisol (T2) & 242,72 & 297,07 & $269,90 \mathrm{a}$ \\
\hline & Rerata & $217,65 \mathrm{~A}$ & $259,08 \mathrm{~A}$ & $(-)$ \\
\hline \multirow{3}{*}{ Bobot segar tanaman $(\mathrm{g})$} & Ultisol (T1) & 99,61 & 155,28 & $127,45 \mathrm{a}$ \\
\hline & Andisol (T2) & 152,58 & 191,20 & $171,89 \mathrm{a}$ \\
\hline & Rerata & $126,10 \mathrm{~A}$ & $173,24 \mathrm{~A}$ & $(-)$ \\
\hline \multirow{3}{*}{ Bobot kering tanaman $(\mathrm{g})$} & Ultisol (T1) & 15,96 & 24,33 & $20,14 \mathrm{a}$ \\
\hline & Andisol (T2) & 12,83 & 24,57 & $18,70 \mathrm{a}$ \\
\hline & Rerata & $14,40 \mathrm{~B}$ & 24,45 A & $(-)$ \\
\hline \multirow{3}{*}{$\begin{array}{l}\text { Panjang akar terpanjang } \\
(\mathrm{cm})\end{array}$} & Ultisol (T1) & 38,86 & 41,03 & $39,95 \mathrm{a}$ \\
\hline & Andisol (T2) & 39,75 & 42,36 & $41,05 \mathrm{a}$ \\
\hline & Rerata & $39,30 \mathrm{~A}$ & $41,7 \mathrm{~A}$ & $(-)$ \\
\hline \multirow{3}{*}{ Volume akar (ml) } & Ultisol (T1) & 18,33 a $B$ & 43,33 a $A$ & 30,83 \\
\hline & Andisol (T2) & 28,33 a $\mathrm{A}$ & 28,33 a $\mathrm{A}$ & 28,33 \\
\hline & Rerata & 23,33 & 35,83 & $(+)$ \\
\hline \multirow{3}{*}{ Bobot segar akar (g) } & Ultisol (T1) & 23,6 & 51,25 & $37,42 \mathrm{a}$ \\
\hline & Andisol (T2) & 38,98 & 39,28 & 39,13 a \\
\hline & Rerata & $31,29 \mathrm{~A}$ & $45,26 \mathrm{~A}$ & $(-)$ \\
\hline \multirow{3}{*}{ Bobot kering akar (g) } & Ultisol (T1) & 6,71 & 10,43 & $8,57 \mathrm{a}$ \\
\hline & Andisol (T2) & 4,29 & 9,05 & $6,67 \mathrm{a}$ \\
\hline & Rerata & $5,5 \mathrm{~A}$ & $9,74 \mathrm{~A}$ & $(-)$ \\
\hline
\end{tabular}

Angka pada baris yang sama diikuti huruf kapital sama dan angka pada kolom yang sama diikuti huruf kecil yang sama menunjukkan tidak berbeda pada uji BNT taraf kepercayaan $95 \%,(+)=$ ada interaksi dan $(-)=$ tidak ada interaksi. 
Tabel 3. Penghambatan B. subtilis terhadap jamur dan bakteri patogen

\begin{tabular}{ccc}
\hline Isolat B. subtilis & $\begin{array}{c}\text { Penghambatan terhadap } \\
\text { C. gloeosporioides }(\%)\end{array}$ & $\begin{array}{c}\text { Zona hambatan terhadap } \\
\text { R. solanacearum }(\mathrm{mm})\end{array}$ \\
\hline B46 & $33,3 \pm 0,3$ & $14,6 \pm 0,4$ \\
B209 & $44,4 \pm 0,3$ & $18,0 \pm 0,4$ \\
B211 & $45,7 \pm 0,3$ & $18,2 \pm 0,4$ \\
B298 & $55,4 \pm 0,3$ & $22,0 \pm 0,4$ \\
B315 & $51,5 \pm 0,3$ & $20,0 \pm 0,4$ \\
\hline
\end{tabular}

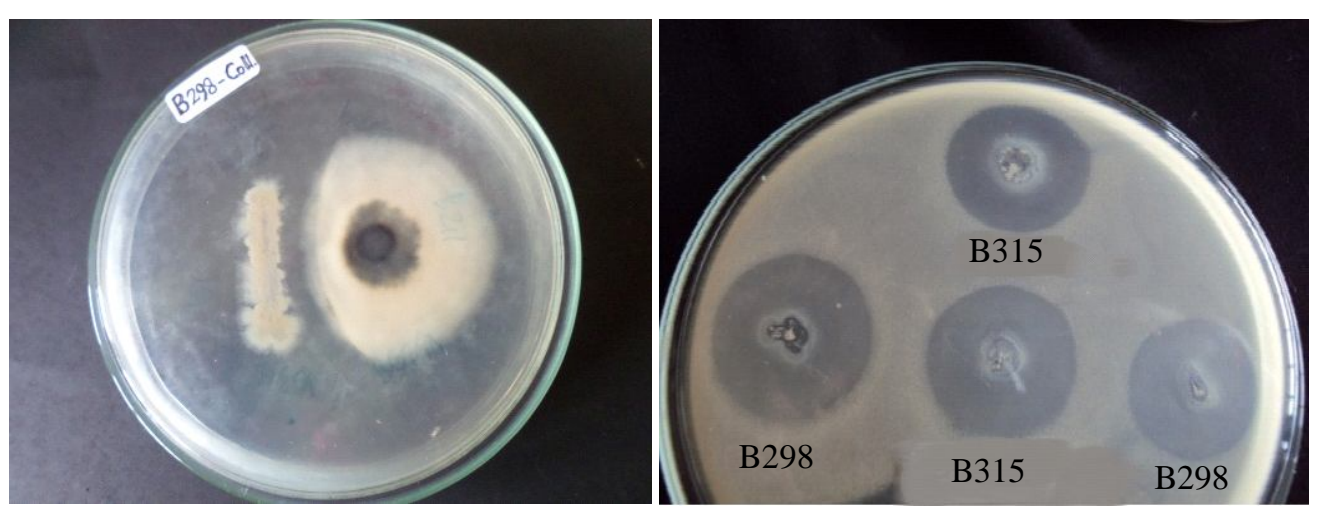

Gambar 3. Penghambatan B. subtilis terhadap C. gloeosporioides dan R. solanacearum

Niamsup, 2013). Metabolit antifungal ditunjukkan dengan adanya siderofor dan beberapa enzim hidrolitik seperti kitinase, protease, lipase dan amilase, dan strain B. subtilis $\mathrm{AI} 01$ dan $\mathrm{AI} 03$ juga mampu menghasilkan IAA sebagai pemacu pertumbuhan tanaman. Hasil penelitian Prihatiningsih \& Djatmiko (2016) memperlihatkan bahwa lima isolat $B$. subtilis dari rizosfer kentang mampu menghasilkan IAA. Produksi kitinase dan amilase ditunjukkan oleh B. subtilis isolat B298 dan B315 (Prihatiningsih \& Djatmiko, 2016) dan Lestari et al. (2017).

\section{SIMPULAN}

Siderofor yang dihasilkan B. subtilis adalah tipe catecholat (isolat B46) dan hydroxamat (isolat B209, B211, B298 dan B315). Aplikasi B. subtilis B298 pada tanah Ultisol meningkatkan serapan Fe sebesar 45,62\%. Aktivitas siderofor dari B. subtilis B298 mampu meningkatkan tinggi tanaman, jumlah daun, bobot kering tanaman dan volume akar berturut-turut sebesar $25,48 \%$, $19,45 \%, 41,10 \%$ dan $34,89 \%$. B. subtilis B298 asal rizosfer kentang dapat diaplikasikan pada tanah ultisol atau podsolik merah kuning yang dapat meningkatkan pertumbuhan tanaman, sehingga membantu mengatasi pelandaian produksi tanaman pada lahan marginal.

\section{SANWACANA}

Terima kasih diucapkan kepada Kementerian Riset, Teknologi, dan Pendidikan Tinggi atas dukungan dananya untuk penelitian Fundamental tahun 2015-2016.

\section{DAFTAR PUSTAKA}

Ahmed E \& Holmstrom SJM. 2014. Siderophores in environmental research: roles and applications. Microb. Biotechnol. 7: 196-208.

Afreen JM \& Chavan MD. 2014. Siderophore Bacillus spp. GN-01 isolated from rhizosphere of ground nut field. Int. J. Pharm. Phytopharmacol. Res. 3(4): 311-313.

Beneduzi A, Ambrosini A, \& Passaglia LMP. 2012. Plant growth-promoting rhizobacteria (PGPR): Their potential as antagonists and biocontrol agents. Genet. Mol. Biol. 35(4): 1044-1051.

Choudhary DK \& Johri BN. 2009. Interaction of Bacillus spp. and plants-with special reference to induced systemic resistance (ISR). Microb. Res. 164(5): 493-513. 
Compant S, Duffy B, Nowak J, Clement C, \& Barka EA. 2005. Use of plant growth-promoting bacteria for biocontrol of plant diseases: principles, mechanism of action, and future prospects. Appl. Environ. Microb. 71(9): 4951-4959.

Dawwam GE, Elbeltagy A, Emara HM, Abbas IH, \& Hassan MM. 2013. Beneficial effect of plant growth promoting bacteria isolated from the roots of potato plant. Ann. Agric. Sci. 58(2): 195-201.

Egamberdiyeva D \& Hoflich G. 2004. Effect of plant growth-promoting bacteria on growth and nutrient uptake of cotton and pea on a semi-arid region of Uzbekistan. J. Arid. Environ.56(2): 293-301.

Ghosh S, Sinha A, \& Sahu C. 2007. Isolation of putative probionts from the intestines of Indian mayor carps. Isr. J. Aquacult-Bamid. 59(3): 127-132.

Hu Q-P \& Xu J-G. 2011. A simple double-layered chrome azurol $\mathrm{S}$ agar (SD-CASA) plate assay to optimize the production of siderophores by a potential biocontrol agent Bacillus. Afr. J. Microbiol. Res. 5(25): 4321-4327.

Kloepper JW, Lifshitz R, \& Zablotowicz RM. 1989. Freeliving bacterial inocula for enhancing crop productivity. Trends Biotechnol. 7(2): 39-43.

Leelasuphakul W, Hemmanee P, \& Chuenchitt S. 2008. Growth inhibitory properties of Bacillus subtilis strains and their metabolites against the green mold pathogen (Penicillium digitatum Sacc.) of citrus fruit. Postharvest Biol. Technol. 48(1): 113121.

Lelliot RA \& Stead DE. 1987. Methods for The Diagnosis of Bacterial Disease of Plant. British Society for Plant Pathology by Blackwel Scientific Publication, Melbourne.

Lestari P, Prihatningsih N, \& Djatmiko HA. 2017. Partial biochemical characterization of crude extract extracellular chitinase enzyme from Bacillus subtilis B298. IOP Conference Series: Materials Science and Engineering. 172012041.

Morikawa M. 2006. Beneficial biofilm formation by industrial bacteria Bacillus subtilis and related species. J. Biosci. Bioeng. 101(1): 1-8.
Muthukumar A \& Venkatesh A. 2013. Exploitaton of fungal and endophytic bacteria for the management of leaf blight of ribbon plant. J. Plant Pathol. Microb. 4(10): 209.

Neilands JB \& Nakamura K. 1991. Detection, determination, isolation characterization and regulation of microbial iron chelates. In. Winkelmann G. Handbook of Microbial Iron Chelates. CRC Press. London.

Nudel C, Gonzalez R, Castaneda N, Mahler G, Actis LA. 2001. Influence of Iron on growth, production of siderophore compound, membrane protein, and lipase activity in acinetobacter calcoaceticus BD 413. Microbiol. Res. 155(4): 263-269.

Perez-Miranda S, Cabirol N, George-Tellez R, Zamudio-Rivera LS, \& Fernandez FJ. 2007. OCAS, a fast and universal method for siderophore detection. J. Microbiol. Methods 70 (1): 127131.

Prihatiningsih N, Arwiyanto T, Hadisutrisno B, \& Widada J. 2015. Mekanisme antibiosis Bacillus subtilis B315 untuk pengendalian penyakit layu bakteri kentang. J. HPT Tropika 15(1): 64-71.

Prihatiningsih N \& Djatmiko HA. 2016. Enzim amilase sebagai komponen antagonis Bacillus subtilis B315 terhadap Ralstonia solanacearum kentang. J. HPT Tropika 16(1): 10-16.

Radhakrishnan M, Samshath KJ, \& Balagurunathan R. 2014. Hydroxamate siderophore from Bacillus sp. SD12 isolated from iron factory soil. Curr. World Environ. 9(3): 990-993.

Saha D, Purkayastha GD, Ghosh A, Isha M, \& Saha A. 2012. Isolation and characterization of two new Bacillus subtilis strains from the rhizosphere of eggplant as potential biocontrol agents. J. Plant Pathol. 94 (1): 109-118.

Sharma A, \& Johri BN. 2003. Growth promoting influence of siderophore-producing Pseudomonas strains GRP3A and $\mathrm{PRS}_{9}$, in maize (Zea mays L.) under iron limiting conditions. Microbiol. Res. 158(3): 243-248. 
Shin SH, Lim Y, Lee SE, Yang NW, \& Rhee JH. 2001. CAS agar diffusion assay for the measurement of siderophore in biological fluids. J. Microbiol. Methods 44(1): 89-95.

Sivasakthi S, Usharani G, \& Saranraj P. 2014. Biocontrol potentiality of plant growth promoting bacteria (PGPR)-Pseudomonas fluorescens and Bacillus subtilis: A review. Afr. J. Agric. Res. 9(16): 12651277.
Thakaew R \& Niamsup H. 2013. Inhibitory activity of Bacillus subtilis BCC 6327 metabolites against growth of aflatoxigenic fungi isolated from bird chili powder. Int. J. Biosci. Biochem. Bioinforma. 3(1): 27-31. 